\title{
Concept of Abetment in the IPC (2013)
}

\author{
Mahmood Rooholamini ${ }^{1}$ \\ ${ }^{1}$ Faculty member (professor) at the Faculty of Law and Theology, Shahid Bahonar University of Kerman. Kerman, \\ Iran
}

Correspondence: Mahmood Rooholamini, Faculty member (professor) at the Faculty of Law and Theology, Shahid Bahonar University of Kerman. Kerman, Iran. E-mail: Mahmood.Rooholamini@gmail.com

Received: January 19, 2017

doi:10.5539/jpl.v10n2p162

Accepted: February 13, $2017 \quad$ Online Published: February 28, 2017

URL: https://doi.org/10.5539/jpl.v10n2p162

\begin{abstract}
Undoubtedly, in many cases, the definition of a legal term or an entity provided by lawyers has significant difference with the definition provided by the institution of the legislature. Therefore, it can be distinguished between the concept of abbeting from a legal perspective, i.e., from the perspective of lawyers and the legal perspective as well as that of the legislature. There is no single definition of abetment from a legal standpoint, but there are various definitions of the term. However, the definitions have much in common. Iranian legislator has not defined "abetment" in the Islamic Penal Code (2003) but addressed some cases of behaviors that may constitute complicity in the crime. In addition, the Iranian legislator has extended the scope of the crimes that shall also apply abetment in IPC (2013). This is contrary to the principle of minimumality of criminal law based on the scope of the criminal law must be limited. In addition, the new law has serious flaws that have the current paper tried to remind objections and provide recommendations for amendments.
\end{abstract}

\section{Introduction}

To explain the concept of abetment, first the term "abet" must be defined on the one hand and on the other hand abetment formation conditions to be examined. Definition of the concept of abetment seems very simple from a legal perspective, because abetment occurs only when there are at least two individuals involved in crime. The Material operstion itself is composed of two parts: First make the arrangements and the operations. Therefore, the abetment is expected only in the case that the operation is done by one person, whether this person is involved in the preparation of crime preliminary arrangements or not and or another person involved in the crime preliminary arrangements without being involved in operations. So from a legal perspective, it is clear what the abetment in a crime is. As we know, many behaviors are criminal in nature, such as transportation, sale and possession of drugs that are known as preventive crimes (Babaei, 2004), but others are not criminal behaviors in nature including transportation, sale and preparation of rope or buying and selling kitchen knives. However, in cases of the allowed by themselves behaviors undertaken to perform a criminal behavior, the legislator considers them criminal. So allowed behaviors are criminal when there are criminal intentions behind the actions. Perhaps the main question here is that what the crime preliminary arrangements. Operations benchmarks are set based on objective and subjective criteria. In this context, it is assumed that the crime preliminary arrangements are whenever two or more people make the decision to commit a criminal act and engage in appearant offensive behaviors without naturally criminal natures. As mentioned, the abetter in a crime must not be involved in operations; therefore, the proven guilty conduct that falls into the operations rules out the abetment concept. So, in summary any conduct seeking committing a crime fit the definition of abetment orovided that the conduct committed does not include the crime operation. For the realization of abetment requires the fulfillment of certain conditions. Abetment occurs under some conditions. On condition is the criminal intention. To fulfill abetment, the abetter and the perpetrator must have the same intention (Mousavi Bojnordi Seyed Mohammad, 2003). For example, if someone incited others to steal and the perpetrator committed murder instead theft, there is no similarity in intentions and the abetment would not be the case. In addition, the commitment of an offensive act by the abetter is required condition for the realization of abetment. Assume that person (A) tells to (B) I can help you steal money from the National Bank. Here, both have the same criminal intention (criminal intention to steal). But suppose that the person (A) does not take any action in order to commit robbery, but (B) attempts to steal from the bank. In this case, although there is a unity with the intention to steal, the person (A) can not be considered an abetter since is not involved in the robbery by any action (Rahmdel Mansor, 2010). The abetter 
must act directly on the crime commitment. Sometimes a person may give to other tools to commit a crime; however, the other person attempts to commit an offense without using the tools, in this context the abetment cannot be realized, as the act of the accused abetter had no effect on crime (Zoqi Taleghani Abdulqafor, 1973). In the end, the crime committed must be done completely for the realization of abetment. It seems that abetment is ruled out if two people have the idea of criminalizing the crime and one attempt to prepare and make arrangements to carry out and the other operates, but crime is not fulfilled (Rezaei Gholam Hossein, 2006). As mentioned, Iranian legislator has not defined abetment, but only provided some cases that can be dealt with abetment.

\section{Examples of Behavior Forming Abetment}

Article 126 of the IPC determines behaviors which can constitute abetment in a crime. This Article provides that "the following persons are abetters:

a. Anyone who persuaded, threatened, bribed, or incited others to commit a crime or a conspiracy or a deceit or abuse of power

b. Anyone who provided tools for committing a crime or offer the crimal the way to commit a crime.

c. Anyone who facilitated crime."

According to Article 126 of the IPC, instances of abetment in three Paragraphs include:

\subsection{Abetment Instances}

- Persuasion: "to persuade someone in any manner, including describing, explaining and or drawing the image of a crime to persuade someone committing a criminal act is considered an instance of abetment" (Ardabil Muhammad Ali, 2014, p.99).

- Threatening: "this means that a person is forced to commit a crime by means of threat to property, prestige and fear of death. As mentioned in the discussion of compulsion, threat is a clear example of spiritual force. But its fulfillment needs several conditions, including those that threat have traditionally be considered as a threat. Also threat must be illegal and completely deprive one of their free wills. The threat is relative and depends on the threatening and threatened circumstances, including mental and physical states, age, personality trait, morality and gender and traditionally must be considered threat that is detected in each case on the court (Marashi Mohammad Hassan, 1996)." It is worth mentioning that "the mere fear of someone or something is not considered a threat, but the agent fear must be originated from intimidating act and be effective" (Ardabil Muhammad Ali, 2014, p. 110).

- $\quad$ Allure: "Allure means to actuate greed and avaricious demands and motivate a sense of favor-seeking. The lure is a special kind of persuasion. The difference is that the main incentive of the perpetrator of a crime is purely financial and material. For instance, to give him an amount of money or promised to give him money and or also promised to propose the project contract before the crime is committed. While in prersuation the means through which the offender is motivated may be financial and non-financial" (Marashi Mohammad Hassan, p.34).

- Incitement: "inciting literally means to move out, move and also means pushing and inciting others to come. Incitement to crime means getting others to commit a crime for any pretext, whether the property, pledges or deception or by encouraging, promoting and in general strengthening the will of the crime such as stimulating a sense of hatred and revenge" (Ardabil Muhammad Ali, 2014, pp. 101-102). According to some lawyers, incitement must be expressed clearly (Ardabil Muhammad Ali, 2014, p. 102). According to some lawyers use of equivocal and ambiguous words can not make up abetment. It seems that ambiguous and non-ambiguous or equivocal words are not the matter but both abetter and accomplice must have the same interpretion of the words. As a result, if anyone stimulates another by a word to apply a specific purpose, but there is no abetment due to lack of unity of intentions if the compliant doesnot mean it and perceives another purpose in the context. According to some lawyers incitement must be in person, so that "the adresseemust be determined. So, if someone, for example, publishes an Article in the newspaper and encourages people to loot speculators warehouse, although his action may be an independent crime, but does not constitute the crime abetment in nature (Ardabil Muhammad Ali, 2014, p. 102)." The question is whether the incitement must be direct or indirect to realize abetment. However, it seems that although the Law is silent in this regard, someone can excite, entice and incite the crime that their stimulation is effective in committing a crime (Ibid). For example, in the case that someone has taken the decision to commit a crime, if another stimulate or encourage them, in this context 
stimulation had no effect ${ }^{1}$. Of course, this argument will be expressed based on a narrow interpretation of the rules and in the interest of the accused charged.

- Intrigue, deceit and abuse of power: The former law used the term deceit along with the word trick. The authors of the new law do not use the word trick in Paragraph (a) of Article 126. Some authors believed that the word trick is the same as deception (Ardabil Muhammad Ali, 2014, p. 104). Trick literally means hidden hatred, machinations, intrigue, seduction and deception means deceit, guile and treason (Ardabil Muhammad Ali, 2014, p. 103).

- Making or preparing committing a crime tool: In some cases the commission of a crime is required to use tools. Or sometimes the crime can be committed without the tool and the tool facliates the commission of the crime. In this context, one may make the tool by themselves or provide the perpetrator with the tool. Legislator tries to stop some crimes by such acts criminalized.

- Offer the perpetrator how to commit a crime: as a rule, people engaged in labor in an organization, company or institution better than anyone know the weaknesses of the organization, company or institution. So their information can be of great help to those who have the intent to commit a crime in such places. Information given must be clear so that the obscure information can not form abetment (Luthermi Lawrence \& Kolb Patrick, 1999, p. 79).

- Facilitate crime: It seems that all aforementioned somehow facilitate the crime. If someone did not persuade or intimidate or bribe the other, and or the tools were not provided for the offender, the crime would not be committed; as a result all these actions have facilitated the crime. All of the above can constitute behaviors considered as abetment. However, all these behaviors could constitute complicity in the crime when there is a unity of intent between the perpetrator and the abetter (Pradel Jean, 2010, p. 305).

\section{Necessity of Unity of Intent between the Abetter and the Accomplice}

It should be noted that the philosophy of Article 126 of the IPC Amendment is to put an end to the important legal issues about complicity in the crime. In fact, in some cases, a person may even knowing of the other criminal intent, provides them with the criminal tool but the offender commits another crime. For example, a person may be provided with a key to a house for stealing, but the perpetrator commits the murder rather than theft, and not only did steal anything, but committed other crimes such as murder and destruction. In this context that the issue raised whether the person who has provided the perpetrator with the tools is only the abetter in the same crime for which tools had been provided or they are abetment in the other committed crimes, as well.

Amendment of Article 126 states that "there must be the unity of intent between the act of abetter and acompliance". Several assumptions seem conceivable in this regard must be addressed:

- The first assumption: one provides another with tools to commit a crime with, the second commits the exact crime; the assumption is clear because there is the unity of intent between the abetter and acompliance.

- The second assumption: one provides another with tools to commit a crime with; the second commits another crime. It seams here we must distinguish between the two assumptions: for example the first offense has been Ali house burglary, but the crime committed is Hassan house burglary. In fact, here the nature of the crime is the same in both but the circumstances differ. It seems that in this case there is no unity of intent between the abetter and acompliance, the scope of the unity of intent must not be limited to the nature of the crime, but must cover all elements of the crime (Bouloc Bernard, 2011, p. 308). There is a fundamental difference between Ali house burglary and Hassan house burglary; probably, if the abetter knew the acompliance wanted a steal Ali house would have provided him with the tools, but if knew he wanted to steal Hassan house would not have provided him with the tools. Therefore, there is no unity of intent between the abetter and acompliance in stealing Hasssan house. The second assumption is when A provides B with the tools to commit robbery, but B commits the murder. In such a case there is unity of intent between the abetter and acompliance. However, an important exception must be noted. In some cases, committing a crime is an introduction of another crime, especially in crimes bound to result. So a person may commit a criminal act that is introduction of other crimes, but does not commit the original crime. In such a context, it seems that unity of intent between the abetter and acompliance encompasses the introductory crime, a person who has attempted to provide the acompliance with the tools is the abetter in the introductory crime. Iranian legislator has forecast profound changes in the Penal Code (2013) in regard to the abetter penalty.

\footnotetext{
${ }^{1}$ The new law in some Articles, for example, paragraph B of Article 38 referred to the effectiveness of the conduct committed.
} 


\section{Abetment Penalty}

Top of Article 127 of the IPC provides that "if the Law or the Sharia doesn't specify the other penalty for the abetter, the sentence is as follows": in this Paragraph, legislative limits penalties foreseen in this Article to the lack of penalty anticipated in Sharia law and the Law. Here, the Law or the Sharia is both un-specified, and this is contrary to the principle of legality of crime and punishment (Elham Gholam Hossein, 2015, p. 305). According to this Article, the judge must study Sharia in the first stage to consider if there is anticipated punishment for abetter in the crime committed.in fact, if he has the knowledge on the issue and examines all other laws in the next stage. Then, assured that the rules have not been set for abetter punishment, he can refer to Article 126 penalties. Penalties provided in Article 126 are as follows:

Paragraph (A) of Article 127 of the IPC provides that "in crimes that legal punishment is deprivation of life or life imprisonment, two or three degree imprisonment."

- Explain Paragraph 127 of the IPC: According to Article 127 first must see whether to crimes that are punishable by deprivation of life are determined in IPC and Sharia or not; because, if there is a determined punishment in IPC and Sharia law Penalties provided for in Paragraph (a) is not applicable. The word deprivation of life actually covers two penalties: first qisas and second the capital punishment. Now the question is what the legislator is meant by the term. If the deprivation of life penalty is qisas; undoubtedly, abetting in the murder is prohibited in Sharia religious sources and requires punishment (Aqaee Nia Hossein, 2010, p. 106). Even some jurists refer to verse 3 of Surah Ma'idah in this regard. This verse reads that do not help in sin and aggression and oppression. In addition to this verse, some jurists explicitly prohibit unlawfulness based on some traditions and the consensus of jurists (Marashi Mohammad Hassan, 1996, pp. 7-10). The abetment in intentional murder is prohibited in jurisdiction and the amount of punishment depends on the judge. Article 843 of the IPC provides that "Whoever commits murder and do not have a complainant or the complainant has put mercy on him, or the qisas is not implemented due to some reasons, if his action might jeopardize law and the security of society or the fear is to encourage others for offense, the court may sentence the offender to imprisonment of three to ten years." Also note to this Article provides that "the penalty for abetment in murder in this case would be imprisonment from one to five years." Legally, it seems that if the murder is deprive dof life by qisas there is no anticipated punishment for the abetter. But if an acompliance is not deprived of life by qisas for any reason, the abetter is not sentenced to five years imprisonment. It seems very strange, because when the murderer is not intended to be punished by qisas, the abetter is sentenced while when the acompliance is deprived of life by qisas there is no anticipated penalty for the abetter. As we said at the top of the Article, the first step, if there is a determined punishment in IPC and Sharia law the same penalties must be applied, and if there is not a determined punishment in IPC and Sharia law the judge can punish envisaged in Paragraph A of Article 127. If the acompliance is not deprived of life by qisas the abetter must be punished according to the provisions of Article 843 of IPC, and if the acompliance is deprived of life by qisas the abetter must be punished in accordance with Paragraph (A) of Article 127. It'll be interesting to see a judicial procedure tends direction. The judge, according to Paragraph A considered two main punishments on first-degree murder in the case that the acompliance is deprived of life by qisas: First, second degree imprisonment punishment of 15 to 25 years in prison and the sentence of third degree imprisonment of over 10 to 15 years.In addition to qisas, death penalty (capital punishment) is another example of depriving of the life. In IPC, the legislator expressly considered the death penalty as the main punishment in many cases. For example, Article 744 of the IPC provides that "Everyone who insults the sanctities of Islam or any of the great prophets and imams (AS) and Hazrat Sedigheh Tahereh if liable to insulting the Prophet is subject to execution"; the legislator considers the punishment for the acompliance without any punishment for the abetter. It seems the abetter can be punished by the legislation in some of the Islamic Penal Code explicitly does not use the term death penalty and provides that the committer is at war. For example, Article 735 of the IPC provides that "Everyone's incites fighting forces or persons related to the serving armed forces to rebellion, escape, surrender or not to perform military duties, if wishes to topple the government or have the defeat of the forces against the enemy is an enemy of God and, if his actions are effective is sentenced to imprisonment of two to ten years, otherwise sentenced to six months to three years in prison". It is noteworthy that under Article 282 of IPC, the death penalty is one of the four punishments considered for the enmity. According to Paragraph (A) of Article 127, of IPC in each case the IPC anticipates the enmity, the abetment mentioned in Criminal offense in Paragraph (A) is punishable. In addition, in cases where the legal punishment is deprivation of life, the abetter is sentenced to second or third degree imprisonment, even in cases where legal penalties are life imprisonment the abetter is also sentenced by the same punishment. It seems that, sentencing the abetter in crimes punishable by deprivation of life and life imprisonment crimes is associated with strict policy on crimes punishable by life imprisonment. Legislator appears to be slightly 
adjusted given that determination of the two or three degree imprisonment is transferred to judge .In addition, legislation in the form of Article 127 Paragraph (B) increases the scope of criminalization of abetment.

- Abetment in the theft and intentional amputation: Paragraph (B) of Article 127 of the IPC Provides that "Abetment in the theft and intentional amputation is punished by five or six degree imprisonment." In fact, the legislator criminalizes the abetment on the basis of the type of sentence given in Paragraph 127 but in Paragraph (B) criminalizes on the basis of the type of crime committed. In fact, the legislature is not in the same policy. The extent of abetment in the theft was criminalized in the former Penal Code under Note 2 of Article 201 with a penalty of one year to three years imprisonment. The new Law did not anticipate any punishment in this case. Accordingly, the punishment envisaged in paragraph (A) is applicable to steal foreseen in article 268 of the IPC. Paragraph B of Article 127 criminalizes abetment in the theft and intentional amputation, as well (Goldozian Iraj, 2012. p. 235). It is noteworthy that under Article 289 of the IPC, "Murder, amputation and benefit are three types of intentional, quasi-intentional and pure error". Criminalization of abetment in the intentional crime is predicted in Paragraph (A), Article 127. The legislator in Article 289 applies the term crime on limb, but does not provide any definition of the term. However, Article 387 of the IPC defines the crime on a limb. Therefore, the definition of "crime on a limb is any harm less than murder, such as amputation of the hand of any damage, injury, and damage on the interests". As you can see, abetment in crimes of injuries to limbs is not criminalized and only amputation is criminalized and apparently abetment in injuries and damage imposed on interest is not a crime. However, the legislation does not specify what he meant amputation. It seems that to recognize this has been the responsibility of the court. In paragraph (B), legislator considers the five degree punishment of imprisonment of two to five years or a six degree imprisonment of more than six months to two years. The former Note 1 of article 269 of the IPC criminalized abetment in battery as that of the amputation and punishable by three months to one year imprisonment. Although the penalties envisaged by the new law are more severe compared to the former law, but surprisingly, despite the adoption of strict policy towards abetment, it is a question why the legislative did not criminalized abetment in the crime of intentional injury. This strict policy goal was further when we found that the legislators extended the scope of the criminalization of offenses in Paragraph (C) of Article 127 to crimes subject to lashings.

- Abetment in crimes subject to lashings: Perhaps one of the most important innovations of the new Islamic Penal Code is the criminalized abetment in crimes subject to lashings. Legislator makes the judge responsible to decide on what crimes are subject to legal punishment of lashing in this paragraph. For example, Article 230 of the IPC punishes the adultery in cases where he is non-marriage with a hundred lashes. It would be much better if the legislature had provided for in Articles 230 abetment with thirty-one to seventy-four lashes of six degrees of punishment. The punishment envisaged for the crime of pimping defined in Article 242 of the Islamic Penal Code referred to prostitution is to "bring together two or more people for adultery or sodomy." According to Paragraph 1 of Article 242 of the Islamic Penal Law "pimping too is subject to the fulfillment of adultery or sodomy." All of these seem to be due to abetment in pimping in accordance with Paragraph (C) of Article 127 of the Islamic Penal Code. As you know, on the basis of Note 1 of Article 242 of the Islamic Penal Code and According to Article 126 Paragraph (C) prostitution is the example of abetment in adultery or sodomy. If we accept that prostitution is abetment, we must admit abetment in prostitution is also a crime under Paragraph (C) of Article 127. Thus, the abetment in adultery or sodomy has been criminalized in the new law. The Paragraph "D" of Article 127 of the Islamic Penal Code criminalizes the abetment in the crime subject to imprisonment.

- Paragraph "D" of Article 127 of the Penal Code enacted in 2013: It seems Paragraph"D" of Article 127 of the Islamic Penal Code is the rewritten Article 21 of the Islamic Penal Code enacted in 1982 with a little change. Article 21 provided that "the person's abetters in crimes are subject to punishment in punishable crimes." Paragraph " $\mathrm{D}$ " of Article 127 provides that "the abettyer punishment is one or two degrees lower than the punishment of the crime". In fact, the Article 21 handed determining the sentence to the judge, but the new law, the legislator has set the sentence. The question is: "what are the punishable crimes? Even on the assumption that we recognize the concept of criminal punishment the question is that whether the scope of crimes must be limited to crimes envisaged in the Penal Code, or encompasses other legislation, as well (Zeraat Abbas, 2013, p. 273).

- Abetment criminalization for specific: In fact, the issue of criminalization for specific in case of logical conditions and in the absence of these conditions seems illogical. In some cases, legislative criminalizes acts that may supply arrangements and abetment to a criminal for specific (Baheri Mohammad, 2014). For example, Article 743 of the IPC provides that "Everyone has the intent to disrupt national security to the war and persuade people for killing each other regardless of whether or not the killing and looting occur, could be sentenced to one to five years in prison." As you know, inciting people to murder and pillage if in the form of abetment and the 
stimulated person to be convicted of murder or pillage. In this case, such as murder and looting can be that abetment in murder and looting have also been achieved. As we know the Iranian law criminalizes the intentional murder. In brief, inciting people to murder with intent to disrupt national security if the murder occurs under the stimulation on the one hand constitute the crime of intentional murder and the other hand applicable to IPC Article 743 and also punishable under this heading. In this context, we could say intentional murder (only through provocation and an attempt to disturb national security) in particular is also criminalized. However, if the murder is not ocurred because abetment in the murder did not happen, thus the abetment has been criminalized in particular in Article 743. If an individual incites people to commit murder in order to disturb national security and the murder occurs due to the stimulating action it is deemed intentional murder committed on the one hand and on the other hand, Article 743 of the Islamic Penal Code will be applicable. In this case there is intellectual diversity. Now the question arises as to which punishment should be punished, the verdict of abetment in intentional murder or penalties foreseen in Article 743. It seems that in such cases the beginning of Article 127 provides that "if there is no specified punishment in the law or the Sharia for the abetment, the abetter punishment is follows". The other face of the coin is that if there is a certain penalty in law or Sharia for abetment, the same penalties is applicable. As a result, given the above assumption it seems that only punishment foreseen in Article 743 of the Islamic Penal Code must be applied. It is worth mentioning briefly that we can speak of abetment in crime that the crime is completely done by the acompliance, otherwise we have to talk about the beginning of the crime.

\section{Conclusion}

It seems that the legislator did not work very well despite several years of experience in the field of criminalization of abetment .The first it appears that the legislator has failed to clearly criminalize the scope of the crimes that would make abetment on any of the various legislative periods. As a result of the lack of transparency has extended the range of punishable abetment in crimes extremely. Even in the IPC (2013) legislators stipulates that "in punishable offenses" means abetment in all the punishable crimes are prone to punishments, again it is not clear predicted only crime in the Islamic Penal Code or other laws are also in place. All crimes are not equal in terms of degree of importance, while the legislator criminalized all the crimes to sentence in term of abetment without regard to the aforementioned. This method of codification does not fit with criminal justice. It seems that the abetment criminalization scope must be limited to important crimes. In many cases, the abetter is under the influence of acompliance emotions, and on the other hand the committed crime is not of such a degree of importance, therefore, to sentence the acompliance seems enough and the abetter punishment does not seem necessary, even if the legislator wants to punish them, it is suggested to select an appropriate punishment according to Paragraph " $\mathrm{D}$ " and sentence them to prison. Therefore, in the first step it is suggested to limite scope of criminalization of abetment to those of particular importance and decriminalizes abetment in the crimes criminalization in the less importanct crimes. In the next step, the legislator avoids criminalization in "general" term for example "punishable offenses". Or at least make clear what punishment for what crime is meant. For example, the legislator can state "in anticipated punishable offenses"; in such a context, in each case, the legislators prohibit behavior and determines punishment for non-compliance, an appropriate sentence will be issued. In fact, criminalization of abetment must be made case by case basis, like that of the criminalization of abetment in the murder (assuming no qisas for acompliance) and abetment in theft and counterfeiting, thereby criminalized. In this context, citizens, lawyers, judges and the legal community clearly understand in what crimes the rules of abetment are criminalized and what the punishment for abetment of any crime is. In the next step, the punishment must be determined based on the importance of crime. Paragraph " $D$ " of Article 127 of the Islamic Penal Code provides that abetter penalties on offense punishable by imprisonment are one to two degrees lower than the punishment for the crime. There are numerous cases where the nature of anticipated punishment for the original crime with the nature of the penalties foreseen in Article 19 Islamic Penal Code is not the same. For example, the penalties foreseen in Article 857 of the Islamic Penal Code are six months to three years imprisonment. If the punishment under Islamic Penal Code Article 19 is a degree 5 penalty, the abetter punishment would be level 6 or 7. The Islamic Penal Code Article 19 punishable degree 6 is more than six months to two years of imprisonment. Moreover, the degree 6 penalty constitutes other penalties such as fines or lashing, etc. The question is whether that the abetter penalty must have the same nature of punishment or not, and the punishment must be one or two degree lower than the original penalty whatever it is, whether in the same nature or not. Accordingly, Note 1of Article 127 provides that "in the case of Paragraph (T) of this Article, the abetter penalty is the same as the legal punishment for crime in nature, except in the case of confiscation of property, and permanent dismissal of the convict that would be a degree 4, 6or 7 fines." Under this Note, if the main penalty established for the perpetrator IS non-criminal confiscation of property, permanent dismissal and publish sentence, the same punishment with a one or two degrees lower sentence is issued for the abetter. For 
example, if the acompliance penalty is imprisonment, the abetter imprisonment penalty is one or two degrees lower. But, if acompliance punishment is the confiscation of property, the abetter is sentenced to degree 4 fines and if the penalty is set for the acompliance is permanent dismissal, the abetter can be sentenced to a six degree fine and if the acompliance penalty sentence is set for publish of crime, and the abetter is sentenced to a seven degree fine. However, it seems that there are many weaknesses in the criminalization of abetment in Iran Criminal Law that need amendment.

\section{References}

Abbas, Z. (2013). General criminal law. Javedaneh Jangal Press.

Abdulqafor, Z. T. (1973). Complicity in the crime. Journal of Bar Association, (124).

Ali, A. M. (2014). General Criminal Law (Vol. II). Mizan.

Ali, B. M., Habibzade, M. J., \& Abad, A. H. N. A. (2004). Preventive crime. Humanities Teacher Magazine, (37).

Elham Gholam Hossein, B. M. (2015). An introduction to the general criminal law (crime and criminals) (Vol. 1). Mizan.

Hassan, M. M. (1996). Abetment. Journal of Justice legal opinions, (1).

Hossein, A. N. (2010). Criminal law (crimes against persons). Mizan.

Hossein, R. G. (2006). Complicity in Murder. Hearing Journal, (60).

Iraj, G. (2012). General criminal law imperatives. Mizan.

Jean, P. (2010). Droit pénal général, CUJAS.

Lawrence, L., \& Patrick, K. (1999). France necessitate of the general criminal law. Translation: Mahmoud Rouholamini. Mizan.

Mansor, R. (2010). Comments on abetment. free legal research magazine, (8-10).

Mohammad, B. (2014). Mirza Ali Akbar Khan Davar (pleadings). General view of the criminal law. Majd.

Mohammad, M. B. S. (2003). Abetment. A study of Matthew, (18).

\section{Copyrights}

Copyright for this article is retained by the author(s), with first publication rights granted to the journal.

This is an open-access article distributed under the terms and conditions of the Creative Commons Attribution license (http://creativecommons.org/licenses/by/4.0/). 